\title{
Study of the constrictor properties of the neobladder under the influence of new chemical compounds in vivo experiment
}

\author{
R.V. Savchuk ${ }^{1}$, orcid: 0000-0002-9917-2413, e-mail: savrus7@rambler.ru \\ F.I. Kostyev ${ }^{1}$, orcid: 0000-0001-6480-564X, e-mail: prof.kostev@gmail.com \\ N.V. Shmatkova ${ }^{2}$, orcid: 0000-0002-3328-4340, e-mail: nshmatkova@ukr.net \\ 1 Odessa National Medical University \\ ${ }^{2}$ Odessa I. I. Mechnikov National University
}

\section{Keywords:}

cystectomy, ileocystoplasty, constrictor properties, new chemical compounds, nivalin, artificial bladder, enterocystometry, in vivo

\section{For citation:}

ДСТУ 8302 2015:

Savchuk R.V., Kostyev F.I., Shmatkova N.V. Study of the constrictor properties of the neobladder under the influence of new chemical compounds in vivo experiment. Урологія. 2021. Т. 25, № 2. C. 130-137. DOI: $10.26641 / 2307-$ 5279.25.2.2021.238237.

APA:

Savchuk, R.V., Kostyev, F.I., \& Shmatkova, N.V. (2021). Study of the constrictor properties of the neobladder under the influence of new chemical compounds in vivo experiment. Urologiya, 25(2), 130-137. DOI: $10.26641 / 2307-5279.25 .2 .2021$. 238237.

\section{SUMMARY}

The orthotopic ileocystoplasty is the most preferred urine derivation method for patients after removal of the bladder. The best quality of life, self-esteem, cosmetic appearance of one's own body, and the possibility of physiological urination characterize the artificial bladder as the "gold standard" of urine derivation. There are a greater number of postoperative complications associated with the functionality of the neobladder, considering the complexity of orthotopic derivation of urine. The autocaturation is required in some patients day or night urinary incontinence, and in the other group, periodic urinary retention. Urinary retention is more common in women up to $43 \%$ compared with $20 \%$ in men, who need intermittent catheterization.

The aim of investigation was to evaluate the possibility of pharmacological correction of contractile activity of mini-pigs neobladder in vivo, under the influence of new chemical compounds and the anticholinesterase drug nivalin.

Materials and methods Experimental studies were performed on 21 female mini-pigs, with an average age of 6 to 14 months. The duration of the experiment was 12 months. Performing of enterocystometry in experimental animals is possible only under anesthesia and, accordingly, only part of the urodynamic parameters can be obtained.

Results. The obtained results of in vivo experimental studies demonstrated the constrictor activity of the studied new chemical compounds. Compound I in comparison with the control group statistically significantly increased basal tone by $62.09 \%$, the amplitude of contractions by $37.34 \%$, and the duration of contractions by $35.71 \%$. The new chemical compound II, in comparison with the control group, showed less pronounced results of constrictor activity, so the basal tone statistically significantly increased by $38.86 \%$, and the amplitude of contractions by $15.0 \%$. Conclusion. Thus, under the influence of new chemical compounds in the conditions of an experimental artificial bladder, constrictor properties are proved, which require further research and study. 
In turn, cholinomimetic nivalin has prospects for use in urology, in particular in patients with hypoactive forms of artificial and neurogenic bladder.

\section{INTRODUCTION Ветуп}

There has been noticeable progress in reconstructive urology, over the past three decades. Especially important results have been obtained in the field of urinary derivation after radical cystectomy [1, 2].

The orthotopic ileocystoplasty is the most preferred urine derivation method for patients after removal of the bladder. The best quality of life, selfesteem, cosmetic appearance of one's own body, and the possibility of physiological urination characterize the artificial bladder as the "gold standard" of urine derivation [3, 4]. Satisfaction with the quality of life after radical cystectomy is an important factor in choosing the method of urine derivation, with a possible choice, more and more patients prefer neobladder [5, 6].

There are a greater number of postoperative complications associated with the functionality of the neobladder, considering the complexity of orthotopic derivation of urine $[7,8]$. The autocaturation is required in some patients day or night urinary incontinence, and in the other group, periodic urinary retention. Urinary retention is more common in women up to $43 \%$ compared with $20 \%$ in men, who need intermittent catheterization $[9,10]$.

An artificial bladder formed from the terminal section of the ileum, pre-detubularized, designed to perform unprogrammed functions of accumulation and emptying, does not always show a reservoir with a stable capacity and satisfactory rates of urine retention and flow. Hypoactive artificial bladder sometimes leads to the accumulation of a large amount of residual urine with intensive development of the bacterial flora and inflammatory processes of the upper urinary tract $[11,12]$.

The issue of urine reflux from the artificial bladder remains debatable. Some authors believe that this is practically not, and others offer options for antireflux protection [13, 14]. The basic requirements for urinary reservoirs formed from the intestine have been developed: a sufficient volume of the urinary reservoir (at least 400-500 ml), providing low intravesical pressure, the absence of retrograde contractions of the urine flow; functional and morphological adaptation, including subsequent spherical change in the shape of the bladder [15, 16]. A thickening of the muscle layer is noted compared with intact ileum, according to a morphological study of the neocyst wall. The act of urination in patients with an artificial bladder occurs according to various authors due to increased pressure in the abdominal cavity and contraction of the muscles of the anterior abdominal wall.

There are no recommendations and theoretical developments on the pharmacological correction of the contractile function of the neobladder at different stages of the postoperative period based on the full information in the available literature. Scientists have proved that the pig's body is closest to humans in its anatomical and morphofunctional features and ideal for studying the pathogenesis of various morphological and biochemical processes.

The aim of investigation was to evaluate the possibility of pharmacological correction of contractile activity of mini-pigs neobladder in vivo, under the influence of new chemical compounds and the anticholinesterase drug nivalin.

\section{MATERIALS AND METHODS \\ Матеріали і методи дослідження}

Experimental studies were performed on 21 female mini-pigs, with an average age of $8 \pm 3,2$ months. The duration of the experiment was 12 months. Performing of enterocystometry in experimental animals is possible only under anesthesia and, accordingly, only part of the urodynamic parameters can be obtained.

The experimental model of the artificial bladder was reproduced by performing cystectomy under anesthesia in animals, followed by ileocystoplasty, implantation of the ureters into a neobladder, and applying an urethroileal anastomosis.

All animal manipulations were carried out in accordance with the International Convention on Animals and the Law of Ukraine "On the Protection of Animals against Cruelty". The study was carried out in accordance with the UK Animal (Scientific Procedures) Act 1986 and EU Directive 2010/63 / EU on the protection of animals used for scientific purposes.

Combined urodynamic study (QUDD) (enterocystotonometry) was performed by authors. The studies were performed on a Delphis KT urodynamic unit (Laborie, Canada) in accordance with the recommendations of the Committee on Standardization of the International Society for Urinary Incontinence (UI). 
The constrictor properties of the test substances were evaluated by changing the basal pressure, amplitude, frequency and duration of contractions in the artificial bladder in vivo, which was measured via an intraurethral catheter in comparison with the group of intact animals and the group of administration of nivalin.

It was found, based on screening and an in vitro experiment, that new chemical compounds affect the contractile activity of the ileum segment in vitro. Among them, two compounds exhibit the highest constrictor activity: pyrrole-2-carbaldehyde 3(dimethylamino) benzoylhydrazone (P2C3DBh, compound I) and 1-methylisatin N, Ndimethylcarbamylhydrazone (1MDCh, compound II), in a concentration $1 \cdot 10^{-3} \mathrm{~mol} / \mathrm{l}$ increasing contractile activity by $54.3 \pm 9.2 \%$ and $51.2 \pm 3.1 \%$, respectively [17]. Compounds were synthesized at the Department of General Chemistry and Polymers of ONU I. I. Mechnikov, their composition and structure is established by a combination of physico-chemical research methods.

The drug Nivalin (galantomine hydrobromide) is a cholinesterase inhibitor obtained from the leaves and flowers of the marsh snowdrop (summer white flower, Leucojum aestivum).

The compounds at the lowest concentration $\left(\mathrm{C}_{\mathrm{ef}}\right)$ were used for in vivo studies, at which the maximum constrictor effect observed. The mass of substance $(\mathrm{m}, \mathrm{mg} / \mathrm{kg}$ ) required for administration to an experimental animal was calculated by the formula:

$$
\mathrm{M}=\mathrm{C}_{\mathrm{ef}} \times \mathrm{M} \times \mathrm{V},
$$

where $\mathrm{M}$ is the molar mass of the substance ( $\mathrm{mol} / \mathrm{l})$, $\mathrm{V}$ - solution volume $0.02 \mathrm{~L}$.

The significance of discrepancies $(\mathrm{P})$ between the values was determined by the criterion $t$ of student. Differences were considered statistically significant at $\mathrm{p}<0.05$.

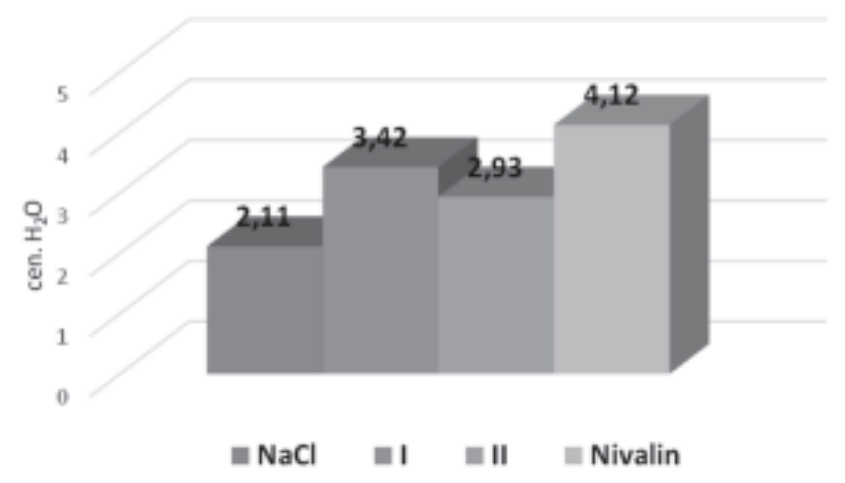

FIGURE 1. Enterocystometric indices of in vivo basal tone of mini-pigs $(n=10): p_{1} \leq 0.05$ significance of differences to the control group $\mathrm{NaCl}$

\section{RESULTS AND DISCUSSION Результати та їх обговорення}

The problem of atony of the artificial bladder is very relevant. The increased tonus of the neobladder will lead to an improvement in urination. The decrease in the level of residual urine will lead to increased persistence of the bacterial flora.

New chemical compounds acting on the smooth muscles of the neobladder cause an increase in tone in the form of an increase in basal pressure, the results of the study are presented in Fig. 1. The basal pressure in the control group of experimental animals was $2.11 \pm 0.54$ (cen. $\mathrm{H}_{2} \mathrm{O}$ ). A statistically significant increase in basal tone was observed by $62.09 \%\left(3.42 \pm 0.32\right.$ cen. $\left.\mathrm{H}_{2} \mathrm{O} \mathrm{p}_{1} \leq 0.05\right)$ in the minipigs group with the introduction of drug I. There was a slight statistically significant increase in basal tone compared to the control group by $38.86 \%(2.93 \pm$ 0.26 cen. $\mathrm{H}_{2} \mathrm{O} \mathrm{p}_{1} \leq 0.05$ ) in the group of experimental animals with the introduction of drug II.

The most intense indicator of basal pressure was recorded increasing by $95.26 \%$ (4.12 \pm 0.11 cen. $\left.\mathrm{H}_{2} \mathrm{O} \quad p_{1} \leq 0.05\right)$ with the introduction of the anticholinesterase drug nivalin.

Enterocystometric measures of the amplitude of contractions of the artificial bladder are presented in Fig. 2. The index of amplitude of contractions was $5.33 \pm 1.06$ (cen. $\mathrm{H}_{2} \mathrm{O} \mathrm{p}_{1} \leq 0.05$ ) in the control group of experimental animals. Against the background of the administration of compound I, an increase in the amplitude of neobladder contractions was noted by $37.34 \% 7.32 \pm 1.03$ (cen. $\mathrm{H}_{2} \mathrm{O} \mathrm{p}_{1} \leq 0.05$ ). There was also a statistically significant increase in amplitude by $15.0 \% 6.13 \pm 1.27$ (cen. $\left.\mathrm{H}_{2} \mathrm{O} \mathrm{p}_{1} \leq 0.05\right)$ in the mini-pigs group with the introduction of the studied compound II. Nivalin, being an anticholinesterase drug, showed maximum constrictor activity, statistically significantly increased the amplitude of contractions of the

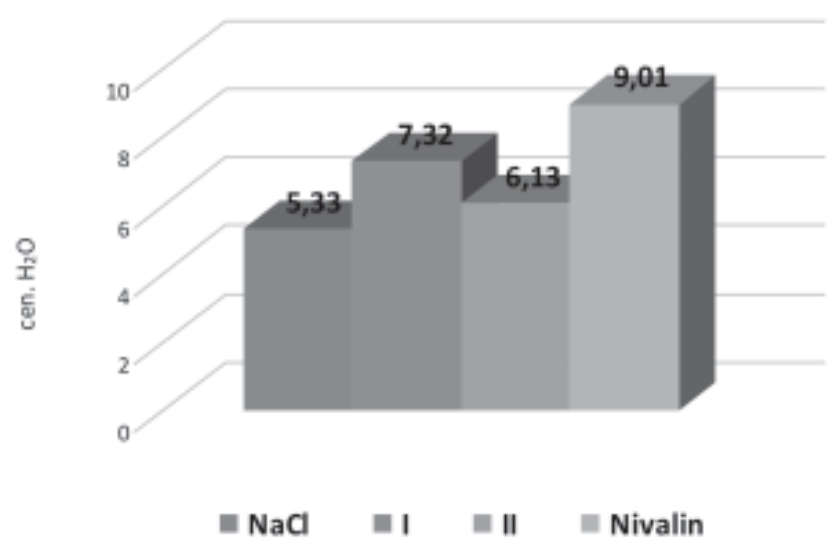

FIGURE 2. Enterocystometric indices of in vivo amplitude of contractions of mini-pigs $(n=10)$ 
artificial bladder by $69.04 \% 9.01 \pm 1.12\left(\right.$ cen $\mathrm{H}_{2} \mathrm{O}$ $\mathrm{p}_{1} \leq 0.05$ ).

The frequency of contractions can be estimated as the frequency of peristalsis of the artificial bladder formed from the terminal ileum, since a single system of innervation of the intestine and neobladder is preserved. The results are shown in Fig. 3. The frequency of contractions in 10 minutes in the control group was $8.3 \pm 0.5$ times. The introduction of the studied compounds I and II led to an increase in the frequency of contractions of the artificial bladder and amounted to $9.04 \pm 0.8$ times $\left(\mathrm{p}_{1}>0.05\right)$ and $9.17 \pm 0.9$ times $\left(\mathrm{p}_{1}>0.05\right)$, respectively, which are not statistically significant. The anticholinesterase compound statistically significantly increased the frequency of contractions by $24.1 \%(10.3 \pm 1.2$ times $\mathrm{p}_{1} \leq 0.05$ ).

The duration of contractions according to enterocystometry of the neobladder is shown in Fig. 4. The duration of contractions was $1.4 \pm 0.14$ sec. the group of experimental control animals. The introduction of a new chemical compound I led to an increase in the duration of the reduction by $35.71 \% 1.9 \pm 0.05 \mathrm{sec} .\left(\mathrm{p}_{1} \leq 0.05\right)$.

The introduction of compound II leads to a statistically not significant increase in the duration of constriction and is $1.6 \pm 0.02 \mathrm{sec} .\left(\mathrm{p}_{1}>0.05\right)$. Cholinomimetic showed a statistically significant increase in the duration of contractions by $42.86 \%$ $2.0 \pm 0.04$ sec. $\left(\mathrm{p}_{1} \leq 0.05\right)$.

The results of in vivo studies of new chemical compounds have demonstrated putative constrictor and antispasmodic properties, which require further research for the possibility of introduction into clinical practice. Many researchers are trying to solve the problem of urinary incontinence in patients with neobladder, so Nathan Hoag suggested injecting botulinum toxin into the conduit wall to reduce the
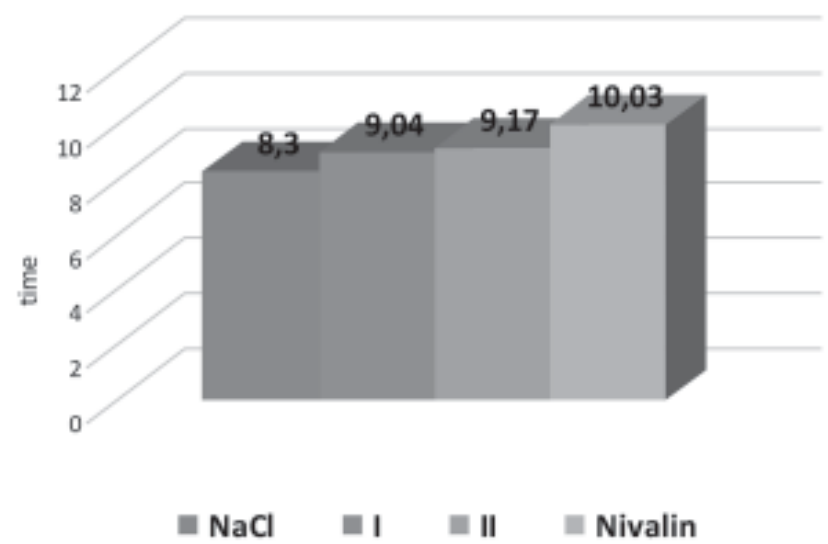

FIGURE 3. Enterocystometric indicators in vivo of the frequency of contractions in 10 minutes of the mini-pigs neobladder $(n=10): p_{1}<0.05$ significance of differences to the control group $\mathrm{NaCl}$. tone, demonstrating stabilization of enteromentric parameters [18].

El-Bahnasawy, in turn, also suggested using verapamil in addition to botulinum toxin to treat nocturnal urinary incontinence in patients with an artifical bladder, remarking a decrease in incontinence [19]. Simma-Chiang studied the effectiveness of artificial sphincters in patients with urinary incontinence after radical cystectomy, proving that sphincter placement is a safe and $90 \%$ effective procedure resulting in reduced incontinence episodes [20].

The main aim of rehabilitation of patients after radical cystectomy with orthotopic bladder formation is to prevent incontinence and hypotension of the neobladder. The occurrence of new chemical compounds, pharmacological agents, and techniques capable of adequately affecting this problem will significantly improve the quality of life of this group of patients.

\section{CONCLUSIONS \\ Висновки}

The artificial bladder, formed from the terminal ileum, is pre-denervated along the mesenteric margin, preserves peristalsis and, given the sharp thickening of the muscle layer, capable to contractile reactions and tone support.

The obtained results of in vivo experimental studies demonstrated the constrictor activity of the studied new chemical compounds. Compound I in comparison with the control group statistically significantly increased basal tone by $62.09 \%$, the amplitude of contractions by $37.34 \%$, and the duration of contractions by $35.71 \%$. The new chemical compound II, in comparison with the control group, showed less pronounced results of

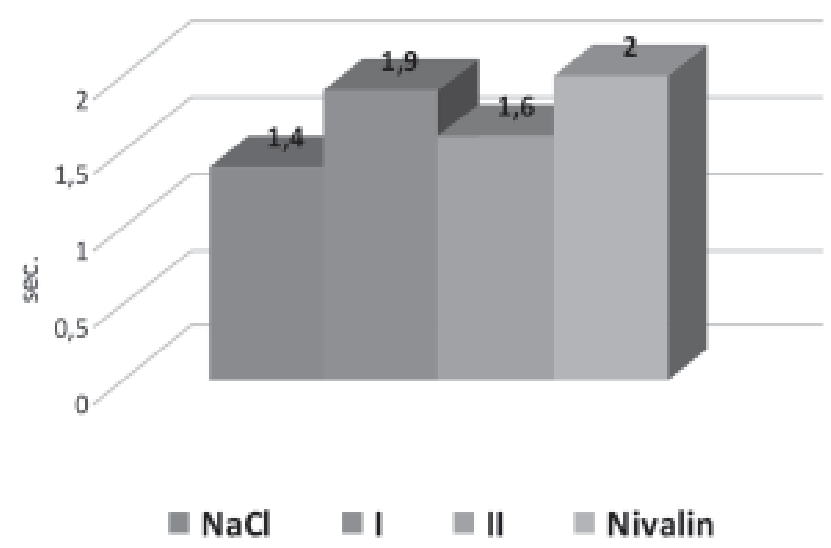

FIGURE 4. Enterocystometric measures in vivo of the duration of contractions of the mini-pigs neobladder $(n=10): p_{1} \leq 0.05$ significance of differences to the control group $\mathrm{NaCl}$ 
constrictor activity, so the basal tone statistically significantly increased by $38.86 \%$, and the amplitude of contractions by $15.0 \%$.

The anticholinesterase drug nivalin has smooth muscle selectivity and showed maximum constrictor activity in the in vivo experiment, so the basal tone statistically significantly increased by $95.26 \%$, the amplitude of contractions by $69.04 \%$, the frequency of contractions by $24.1 \%$, and the duration of contractions by $42.86 \%$.

Thus, under the influence of new chemical compounds in the conditions of an experimental artificial bladder, constrictor properties are proved, which require further research and study.

In turn, cholinomimetic nivalin has prospects for use in urology, in particular in patients with hypoactive forms of artificial and neurogenic bladder.

\section{ІНФОРМАЦЯ ПРО КОНФЛІКТ ІНТЕРЕСІВ Conflict of interest}

None declared.

\section{ACKNOWLEDGMENT Подяка}

I would like to express my gratitude to Oleg Ushakov for his help in the research and support at all stages of the experiment.

\section{СПИСОК ЛІТЕРАТУРИ References}

1. Khetrapal P., Conroy S., Kelly J.D., Catto J.W.F. Comparing open-radical cystectomy and robot-assisted radical cystectomy: current status and analysis of the evidence. Curr Opin Urol. 2020. Vol. 30, No. 3. P. 400406. Doi: 10.1097/MOU.0000000000000755.

2. Cai P.Y., Khan A.I., Shoag J.E., Scherr D.S. Robotic Radical Cystectomy in the Contemporary Management of Bladder Cancer. Urol Clin North Am. 2021. V ol. 48, No. 1. P. 45-50. Doi: 10.1016/ j.ucl.2020.09.003.

3. Ghosh A., Somani B. Recent trends in postcystectomy health-related quality of life (QoL) favours neobladder diversion: Systematic review of the literature. Urology. 2016. Vol. 93. P. 22-26. Doi: 10.1016/j.urology.2015.12.079.

4. Lee R., Abol-Enein H., Artibani W. et al. Urinary diversion after radical cystectomy for bladder cancer: Options, patient selection, and outcomes. BJU Int. 2014. Vol. 113. P. 11-23. Doi: 10.1111/bju.12121.

5. Gacci M., Saleh O., Cai T. et al. Quality of life in women undergoing urinary diversion for bladder cancer: results of a multicenter study among longterm disease-free survivors. Health Qual Life
Outcomes. 2013. Vol. 11. P. 43. Doi: 10.1186/14777525-11-43.

6. Cerruto M., D'Elia C., Siracusano S. et al. Systematic review and meta-analysis of non-RCTs on health-related quality of life after radical cystectomy using validated questionnaires: Better results with orthotopic neobladder vs. ileal conduit. Eur J Surg Oncol. 2016. Vol. 42. P. 343-360. Doi: 10.1016/j.ejso.2015.10.001.

7. Kanno T., Ito K., Sawada A. et al. Complications and reoperations after laparoscopic radical cystectomy in a Japanese multicenter cohort. Int $J$ Urol. 2019. Vol. 26, No. 4. P. 493-498. Doi: 10.1111/ iju.13917.

8. Rodriguez Faba O., Parada Moreno R., Malca L., Palomino Marthnez A., Nervo N., Breda A., Esquinas C., Palou J. Postoperative management of radical cystectomy. Review of the evidence on the prevention and treatment of urological complications. Actas Urol Esp (engl ed.). 2018. Vol. 42, No. 3. P. 143-151. Doi: 10.1016/j.acuro.2017.04.006.

9. Akand M., Kilic O., Bocu K., Harmankaya I., Aydogan F.M. First experience with a new form of orthotopic ileal neobladder (Leuven N-Pouch) following radical cystectomy. Turk J Urol. 2019. Vol. 45, P. 150-155. Doi: 10.5152/tud.2019.68704.

10. Hirobe M., Tanaka T., Shindo T. et al. Complications within 90 days after radical cystectomy for bladder cancer: results of a multicenter prospective study in Japan. Int J Clin Oncol. 2018. Vol. 23, No. 4. P. 734-741. Doi: 10.1007/ s10147-018-1245-z.

11. Ameeta L., Nayak B., Cagiannos I. et al. Urinary function following radical cystectomy and orthotopic neobladder urinary reconstruction. Can Urol Assoc J. 2018. Vol. 12. P. 181-186. Doi: 10.5489/cuaj.4877.

12. Lee R., Abol-Enein H., Artibani W. et al. Urinary diversion after radical cystectomy for bladder cancer: Options, patient selection, and outcomes. BJU Int. 2014. Vol. 113, No. 1. P. 11-23. Doi: 10.1111/bju.12121.

13. Nagele U., Kuczyk M., Anastasiadis A.G. Radical Cystectomy and Orthotopic Bladder Replacement in Females. Eur. Urol. 2006. Vol. 50. P. 249-257. Doi: 10.1016/j.eururo.2006.05.037.

14. Studer U., Burkhard F., Schumacher M., Kessler T. et al. Twenty Years Experience With an Ileal - Orthotopic Low Pressure Bladder Substitute Lessons to be Learned. J. Urol. 2006. Vol. 176. P. 161-166. Doi: 10.1016/S0022-5347(06)00573-8.

15. Moon A., Vasdev N., Thorpe A.C. Continent Urinary Diversion. Indian J Urol. 2013. Vol. 29(4). P. 303-309. Doi: 10.4103/0970-1591.120111.

16. Morrison C.D., Kielb S.J. Use of Bowel in Reconstructive Urology: What a Colorectal Surgeon Should Know. Clin Colon Rectal Surg. 
2017. Vol. 30(3). P. 207-214. Doi: 10.1055/s-00371598162.

17. Savchuk R., Zhukovsky D. Regulation of the Contractile Activity of the Small Intestine Isolated Segment in Vitro. International Journal of Pharmacy and Chemistry. 2017. Vol. 3. P. 62-66. Doi: 10.11648/ j.ijpc.20170305.11.

18. Hoag N., Tse V., Wang A., Chung E., Gani J. Intravesical OnabotulinumtoxinA Injection for Overactive Orthotopic Ileal Neobladder: Feasibility and Efficacy. Int Neurourol J. 2016. Vol. 20(1). P. 81-85. Doi: 10.5213/inj.1630380.190.

19. El-Bahnasawy M.S., Shaaban H., Gomha M.A., Nabeeh A. Clinical and urodynamic efficacy of oxybutynin and verapamil in the treatment of nocturnal enuresis after formation of orthotopic ileal neobladders. A prospective, randomized, crossover study. Scand J Urol Nephrol. 2008. Vol. 42(4). P. 344351. Doi: 10.1080/00365590701832726.

20. Simma-Chiang V., Ginsberg D.A., Teruya K.K., Boyd S.D. Outcomes of artificial urinary sphincter placement in men after radical cystectomy and orthotopic urinary diversions for the treatment of stress urinary incontinence: the University of Southern California experience. Urology. 2012. Vol. 79(6). P. 13971401. Doi: 10.1016/j.urology.2012.02.006.

\section{REFERENCES \\ Список літератури}

1. Khetrapal, P., Conroy, S., Kelly, J.D., \& Catto, J.W.F. (2020). Comparing open-radical cystectomy and robot-assisted radical cystectomy: current status and analysis of the evidence. Curr Opin Urol., 30(3), 400-406. Doi: 10.1097/ MOU.0000000000000755.

2. Cai, P.Y., Khan, A.I., Shoag, J.E., \& Scherr, D.S. (2021). Robotic Radical Cystectomy in the Contemporary Management of Bladder Cancer. Urol Clin North Am., 48(1), 45-50. Doi: 10.1016/j.ucl.2020.09.003.

3. Ghosh, A., \& Somani, B. (2016). Recent trends in postcystectomy health-related quality of life (QoL) favours neobladder diversion: Systematic review of the literature. Urology, 93, 22-26. Doi: 10.1016/j.urology.2015.12.079.

4. Lee, R., Abol-Enein, H., Artibani, W., et al. (2014). Urinary diversion after radical cystectomy for bladder cancer: Options, patient selection, and outcomes. BJU Int., 113, 11-23. Doi: 10.1111/ bju. 12121.

5. Gacci, M., Saleh, O., Cai, T., et al. (2013). Quality of life in women undergoing urinary diversion for bladder cancer: results of a multicenter study among long-term disease-free survivors. Health Qual Life Outcomes., 11, 43. Doi: 10.1186/1477-7525-11-43.
6. Cerruto, M., D'Elia, C., Siracusano, S., et al. (2016). Systematic review and meta-analysis of nonRCTs on health-related quality of life after radical cystectomy using validated questionnaires: Better results with orthotopic neobladder vs. ileal conduit. Eur J Surg Oncol., 42, 343-360. Doi: 10.1016/ j.ejso.2015.10.001.

7. Kanno, T., Ito, K., Sawada, A., et al. (2019). Complications and reoperations after laparoscopic radical cystectomy in a Japanese multicenter cohort. Int J Urol., 26(4), 493-498. Doi: 10.1111/iju.13917.

8. Rodrnguez Faba, O., Parada Moreno, R., Malca, L., Palomino Marthnez, A., Nervo, N., Breda, A., Esquinas, C., \& Palou, J. (2018). Postoperative management of radical cystectomy. Review of the evidence on the prevention and treatment of urological complications. Actas Urol Esp (engl ed.), 42(3), 143-151. Doi: 10.1016/j.acuro.2017.04.006.

9. Akand, M., Kilic, O., Bocu, K., Harmankaya, I., \& Aydogan, F.M. (2019). First experience with a new form of orthotopic ileal neobladder (Leuven NPouch) following radical cystectomy. Turk J Urol., 45, 150-155. Doi: 10.5152/tud.2019.68704.

10. Hirobe, M., Tanaka, T., Shindo, T., et al. (2018). Complications within 90 days after radical cystectomy for bladder cancer: results of a multicenter prospective study in Japan. Int J Clin Oncol., 23(4), 734-741. Doi: 10.1007/s10147-0181245-z.

11. Ameeta, L., Nayak, B., Cagiannos, I., et al. (2018). Urinary function following radical cystectomy and orthotopic neobladder urinary reconstruction. Can Urol Assoc J., 12, 181-186. Doi: 10.5489/ cuaj.4877.

12. Lee, R., Abol-Enein, H., Artibani, W., et al. (2014). Urinary diversion after radical cystectomy for bladder cancer: Options, patient selection, and outcomes. BJU Int., 113(1), 11-23. Doi: 10.1111/ bju.12121.

13. Nagele, U., Kuczyk, M., \& Anastasiadis, A.G. (2006). Radical Cystectomy and Orthotopic Bladder Replacement in Females. Eur. Urol., 50, 249-257. Doi: 10.1016/j.eururo.2006.05.037.

14. Studer, U., Burkhard, F., Schumacher, M., Kessler, T., et al. (2006). Twenty Years Experience With an Ileal - Orthotopic Low Pressure Bladder Substitute - Lessons to be Learned. J. Urol., 176, 161-166. Doi: 10.1016/S0022-5347(06)00573-8.

15. Moon, A., Vasdev, N., \& Thorpe, A.C. (2013). Continent Urinary Diversion. Indian J Urol., 29(4), 303-309. Doi: 10.4103/0970-1591.120111.

16. Morrison, C.D., \& Kielb, S.J. (2017). Use of Bowel in Reconstructive Urology: What a Colorectal Surgeon Should Know. Clin Colon Rectal Surg., 30(3), 207-214. Doi: 10.1055/s-00371598162. 
17. Savchuk, R., \& Zhukovsky, D. (2017). Regulation of the Contractile Activity of the Small Intestine Isolated Segment in Vitro. International Journal of Pharmacy and Chemistry, 3, 62-66. Doi: 10.11648/ j.ijpc.20170305.11.

18. Hoag, N., Tse, V., Wang, A., Chung, E., \& Gani, J. (2016). Intravesical OnabotulinumtoxinA Injection for Overactive Orthotopic Ileal Neobladder: Feasibility and Efficacy. Int Neurourol J., 20(1), 81-85. Doi: 10.5213/inj.1630380.190.

19. El-Bahnasawy, M.S., Shaaban, H., Gomha, M.A., \& Nabeeh, A. (2008). Clinical and urodynamic

\section{PEФEPAT}

\section{Вивчення констрикторних властивостей необладдера під вплив нових хімічних сполук в експерименті in vivo}

Р.В. Савчук, Ф.Іे. Костев,

Н.В. Шматкова

Ортотопічна ілеоцистопластика є найбільш привабливим методом відведення сечі для пацієнтів після видалення сечового міхура. Найкраща якість життя, самооцінка, косметичний вигляд власного тіла та можливість фізіологічного сечовипускання характеризують артифіційний сечовий міхур як «золотий стандарт» відведення сечі. І̇снує значна кількість післяопераційних ускладнень, пов'язаних з функціональністю неоциста, враховуючи складність ортотопічного відведення сечі. Найчастіше зустрічається нетримання сечі та атонія неоциста. Гіпотонія потребує аутокататеризації при періодичній затримці сечі, яка частіше зустрічається у жінок до $43 \%$ порівняно з $20 \%$ у чоловіків.

Метою дослідження було оцінити можливість фармакологічної корекції скорочувальної активності необладдера mini-pigs in vivo під впливом нових хімічних сполук та антихолінестеразного препарату ніваліну.

Матеріали та методи. Експериментальні дослідження були проведені на 21 самці mini-pigs, середнім віком від 6 до 14 місяців. Тривалість експерименту становила 12 місяців. Виконання ентероцистометрії у експериментальних тварин можливе лише під наркозом і, відповідно, можна отримати лише частину уродинамічних параметрів.

Результати. Отримані результати експериментальних досліджень in vivo продемонстрували констрикторну активність досліджуваних нових хімічних сполук. З'єднання I порівняно з контрольною групою статистично достовірно підвищило базальний тонус на 62,09\%, амплітуду ско- efficacy of oxybutynin and verapamil in the treatment of nocturnal enuresis after formation of orthotopic ileal neobladders. A prospective, randomized, crossover study. Scand J Urol Nephrol., 42(4), 344-351. Doi: 10.1080/00365590701832726.

20. Simma-Chiang, V., Ginsberg, D.A., Teruya, K.K., $\&$ Boyd, S.D. (2012). Outcomes of artificial urinary sphincter placement in men after radical cystectomy and orthotopic urinary diversions for the treatment of stress urinary incontinence: the University of Southern California experience. Urology, 79(6), 1397-1401. Doi: 10.1016/j.urology.2012.02.006.

\section{PEФЕРАТ}

\section{Изучение констрикторных свойств необладдера под влиянием новых химических соединений в эксперименте in vivo}

\author{
Р.В. Савчук, Ф.И. Костев, \\ Н.В. Шматкова
}

Ортотопическая илеоцистопластика является наиболее привлекательным методом отведения мочи у пациентов после удаления мочевого пузыря. Лучшее качество жизни, самооценка, косметический вид собственного тела и возможность физиологического мочеиспускания характеризует артифициальный мочевой пузырь как «золотой стандарт» отведения мочи. Существует большое количество послеоперационных осложнений, связанных с функционированием неоциста, учитывая сложность ортотопического отводения мочи. Иногда встречается недержание мочи и атония неоциста. Гипотония требует аутокататеризации при периодической задержке мочи, которая чаще встречается у женщин до 43\%, по сравнению с $20 \%$ у мужчин.

Целью исследования было оценить возможность фармакологической коррекции сократительной активности необладдера mini-pigs in vivo под влиянием новых химических соединений и антихолинэстеразного препарата нивалина.

Материалы и методы. Экспериментальные исследования были проведены на 21 самках minipigs, средним возрастом от 6 до 14 месяцев. Продолжительность эксперимента составляла 12 месяцев. Выполнение энтероцистометрии у экспериментальных животных возможно только под наркозом и, соответственно, можно получить только часть уродинамических параметров.

Результаты. Полученные результаты экспериментальных исследований in vivo продемонстрировали констрикторную активность исследуемых новых химических соединений. Соединение I по сравнению с контрольной группой 
рочень на $37,34 \%$ та тривалість скорочень на $35,71 \%$. Нова хімічна сполука II, порівняно 3 контрольною групою, показала менш виражені результати констрикторної діяльності, тому базальний тонус статистично достовірно підвищився на $38,86 \%$, а амплітуда скорочень - на $15,0 \%$.

Висновок. Таким чином, під впливом нових хімічних сполук в умовах експериментального штучного сечового міхура доведені констрикторні властивості, які потребують подальших досліджень. У свою чергу, холіноміметик нівалін має перспективи для використання в урології, зокрема у пацієнтів з гіпоактивними формами штучного та нейрогенного сечового міхура.

Ключові слова: цистектомія, ілеоцистопластика, констрикторні властивості, нові хімічні сполуки, нівалін, штучний сечовий міхур, ентероцистометрія, in vivo. статистически достоверно повысило базальный тонус на $62,09 \%$, амплитуду сокращений на $37,34 \%$ и продолжительность сокращений на $35,71 \%$. Новое химическое соединение II, по сравнению с контрольной группой, показала менее выраженные результаты констрикторной деятельности, поэтому базальный тонус статистически достоверно повысился на 38,86\%, а амплитуда сокращений - на 15,0\%.

Выводы. Таким образом, под влиянием новых химических соединений в условиях экспериментального искусственного мочевого пузыря доказаны констрикторные свойства, которые требуют дальнейших исследований и изучений. В свою очередь, холиномиметик нивалин имеет перспективы для использования в урологии, в частности у пациентов с гипоактивными формами искусственного и нейрогенного мочевого пузыря.

Ключевые слова: цистэктомия, илеоцистопластика, констрикторные свойства, новые химические соединения, нивалин, искусственный мочевой пузырь, энтероцистометрия, in vivo. 